\title{
6
}

\section{Myanmar's transition without justice}

\author{
Catherine Renshaw
}

The rape and murder of Maran Lu Ra and Tangbau Hkawn Nan Tsin, which took place in January 2015 in a small village in Shan State, Myanmar, became a focal point for civil society activism around issues of justice and impunity during Myanmar's transition to democracy. ${ }^{1}$ There are several reasons for this. Of note, first, is the character of the victims. Ra and Tsin were young female schoolteachers and members of one of Myanmar's minority ethnic groups, the Kachin. From the 1960s until 1994, the Kachin Independence Army (KIA) waged war against Myanmar's military, seeking greater autonomy for Kachin State (Sadan 2015). During the decades of insurgency, Kachin women and children experienced severe human rights violations at the hands of both Myanmar's military and ethnic armies. A ceasefire between the government and the KIA broke down in 2011, leading to the displacement of civilians and to increasing levels of human rights violations. $\mathrm{Ra}$ and Tsin came to represent, for many, the suffering of women and children during the government's long-running civil conflict with armed ethnic organisations.

1 Throughout the chapter, the term 'Burma' is used when the text refers to the country and 'Burmese' for the people, before 1990. 'Myanmar' is used for the country after this date, as the country was officially renamed in 1990. The same applies to 'Rangoon' and 'Yangon'. 'Myanmar' refers to citizens of the country as a whole. 'Bamar' is used to describe the ethnic group that has dominated governance of the country and is the most numerous in the country. 
Second, the suspected perpetrators were members of the military's Light Infantry Battalion 503, which had been stationed in the village at the time of the crimes. The inadequate police investigation into the case highlighted the fact that Myanmar's democratisation, which began in 2010 with the election of a nominally civilian government, had not ended military impunity. Legal and administrative barriers to justice remained in place: the military was not subject to the jurisdiction of national courts; the police force lacked institutional independence; and the judiciary was not impartial. The perfunctory and flawed investigation into the rape and murder of Ra and Tsin and the failure on the part of authorities to charge anyone for the crimes reflected the systemic justice failures that persisted into Myanmar's transition.

Third, $\mathrm{Ra}$ and Tsin were members of the powerful Kachin Baptist Convention (KBC), a Christian religious organisation dominant in Kachin State and across Myanmar's largely Christian north. In the wake of the crimes against $\mathrm{Ra}$ and Tsin and the subsequent police investigation, the $\mathrm{KBC}$ formed its own Truth-Finding Committee and conducted its own investigation into the crimes. The $\mathrm{KBC}$ investigation established serious procedural failures by the police and uncovered evidence that strongly suggested the culpability of the military. The case of Ra and Tsin brings to the fore the role assumed by civil society in the pursuit of truth and justice during Myanmar's transition, in a context where the primary political actors - the military and the country's major democratic political party, the National League for Democracy (NLD) - have strong reasons not to pursue a transitional justice agenda. In the face of resistance from these actors, the KBC and other civil society organisations articulate a unique and powerful perspective on the forms and processes that justice could take during Myanmar's transition to democracy.

This chapter shows how measures to advance justice during Myanmar's transition are being led from the bottom up by community-based groups, local religious organisations and non-governmental organisations (NGOs), without support from key political actors in the transition. ${ }^{2}$ The conception of justice put forward by organisations such as the KBC focuses on securing justice in individual cases such as those of $\mathrm{Ra}$ and Tsin, in order to deter further crimes, end military impunity and bear

2 In this chapter, I use the term 'civil society' and 'civil society organisations' to refer to different forms of civil activism between the family and the state, including faith-based organisations (Heidel 2006). 
witness to the wrong done to victims. There are also, however, broader and more complex forms of justice that are also promoted by civil society organisations. The statements from local organisations, particularly religious organisations and women's groups, have linked the conflict in Kachin State and elsewhere to the economic exploitation of the people, and they have demanded a form of justice that includes constitutional reform, genuine federalism and protection of minority rights. As well as retributive justice in individual cases, many civil society organisations call for the return of traditional ownership of land, measures to safeguard the environment, the protection of language, culture and religion, and an end to discrimination against ethnic minorities: the demand is for a form of justice that is both specific (addressing individual cases such as those of $\mathrm{Ra}$ and $\mathrm{Tsin}$ ) and broad (addressing structural social and economic inequalities). In the early years of Myanmar's transition, the government was deficient in addressing both forms of justice.

As several scholars have pointed out, narrow definitions of 'civil society organisations' and 'community-based organisations' are not useful in the Burmese context, because they impede a full understanding of social organising and social change in the country (Kramer 2011; PrasseFreeman 2012; see also Lidauer 2012). From 1962, under the rule of General Ne Win, three main types of civil society organisation were permitted to exist: (1) organisations affiliated with the government, whose activities were restricted largely to the promotion of literature and culture; (2) the Buddhist monkhood (sangha); and (3) Christian churches. It was not until the early 1990s that United Nations agencies and international NGOs began sponsoring the activities of local NGOs, focusing mainly on healthcare and health education services, HIV/AIDS prevention, child protection and microfinance (South 2008). In the late 1990s, as economic difficulties and the crushing sanctions policies of the United States and the European Union undermined the livelihood of millions of Burmese (Renshaw 2017), independent local charitable organisations emerged. In 2008, in the wake of Cyclone Nargis, local community organisations carried out the work of rescue and repair in large parts of the country (Renshaw 2014). Turnell argues that even before transition began, civil society organisations were indispensable parts of the Burmese political economy, providing social goods and essential services that the military was incapable of delivering (Turnell 2008; Prasse-Freeman 2012). Following the 2010 election and the liberalisation of laws relating to freedom of association, the space for civil society organisations dramatically increased 
across the country, and since then they have played a powerful and shifting role in Myanmar's transition to democracy. In this chapter, I use the expression 'civil society organisations' (CSOs) to refer to voluntary, autonomous associations and networks of organised civil activism existing between the family and the state (Hann 2011; South 2008) including faith-based groups but not private economic actors or political parties. On this definition, on one count, Myanmar has more than 200,000 civil society organisations (Heidel 2006, 43).

South, in his study of civil society organisations in Myanmar, distinguishes between NGOs and community-based organisations (CBOs). CBOs are locally managed grassroots organisations where members are the main beneficiaries. NGOs, in contrast, are not necessarily from the community - though they work for community members - and they may be local, national or international. One of my purposes in this chapter is to demonstrate this difference and to highlight the way in which the nature and characteristics of different civil society organisations shape the way they respond to questions of transitional justice. I focus on one of Myanmar's ethnic minority states, Kachin, to explore the transitional justice work being undertaken by CSOs and NGOs in that state. In Kachin, both NGOs and CBOs have been active in progressing debate about transitional justice - but in notably different ways. From the perspective of a community-based organisation, I consider the transitional justice work of the Kachin Baptist Convention, which is the most influential church in a state in which more than 90 per cent of the Kachin population is Christian (two-thirds Baptist and one-third Roman Catholic) (Jacquet 2015). I also consider the work of a prominent NGO with international links, ND-Burma, and its efforts to record and collate evidence of historic and ongoing human rights abuses carried out by the military.

This chapter begins by analysing the dynamics of Myanmar's transition to democracy, and explains why in the early years of the transition the major political actors had no appetite for questions of transitional justice. It then discusses the 'peace before justice' argument in the context of Myanmar. It then charts the rise and significance of civil society organisations within Kachin State and explains why organisations such as the KBC carry such legitimacy within local communities. Finally, the chapter outlines the singular contribution of community-based organisations in advocating for justice during the early years of Myanmar's transition to democracy. 


\section{The nature of Myanmar's transition to democracy}

Myanmar is in the early years of democratic transition. In 2010, after 22 years of direct rule, Myanmar's military government withdrew to make way for elections and the assumption of power by a nominally civilian government. The democratic opposition party, the NLD, boycotted the elections, which were won by the military-backed Union Solidarity and Development Party (USDP). ${ }^{3}$ There was deep scepticism, in the immediate aftermath of the 2010 elections, about whether the military intended to allow genuine democratic reform. But between 2010 and 2015, under President Thein Sein, the new government undertook a program of liberalisation, releasing political prisoners, legalising trade unions, allowing public political gatherings, easing press censorship and permitting the teaching of ethnic minority languages in schools across Myanmar (Renshaw 2016). The government also made renewed efforts to end decades-long civil conflict with ethnic armies. In 2011, Aung San Suu Kyi, leader of the NLD, declared that she trusted President Thein Sein to pursue further democratisation and she urged the people to do likewise. In 2012, the NLD contested seats in federal by-elections and Aung San Suu Kyi herself was elected to parliament. In the general elections of 2015, the NLD swept to power. Suu Kyi, who was married to a British citizen and whose sons hold British passports, was barred from becoming president by a special provision in the Constitution that precludes anyone whose spouse or children 'hold allegiance to a foreign power'. In 2016 Suu Kyi appointed herself Special Counsellor of State, a role that she said was 'above the President' (Holmes 2016).

Myanmar's transition is 'liberation from above' or 'regime-initiated liberalisation' (Huntington 1991). It is the result of a decision on the part of the military to withdraw from direct rule and affect an orderly transfer of power to a civilian government. From the military's perspective, the success of the transition depended on four factors: (i) cooperation from the country's pro-democracy political party, the NLD, and its iconic leader Aung San Suu Kyi, in the timing and mode of transition; (ii) guarantees about preserving the autonomy of the military and a political role for

3 Electoral laws required the National League for Demcocracy (NLD) to expel Aung San Suu Kyi, because she had a criminal record. The NLD refused to do this, which meant that the party could not be registered or stand candidates. 
the military in the life of the state; (iii) a guarantee that there would be no prosecution of military officers for crimes committed while the military was in power; (iv) achieving peace with the various armed ethnic groups that had been in conflict with government military forces since the country gained independence from the British at the end of the Second World War (Renshaw 2013).

Between 2010 and 2015, transition proceeded in accordance with the script laid out by the military. First, Suu Kyi convinced hardliners within her party that the NLD should be a junior partner in the militaryled process of gradual democratic reform. The NLD abandoned its longstanding demand for the reinstatement of the results of the 1990 elections, which the NLD won but the military refused to recognise, and ended its campaign of civil disobedience and unlawful gatherings. The new government's strongest claim to credibility - both domestically and internationally - was Suu Kyi's endorsement of the government's plan for democratisation (Myers 2011).

Second, the military ensured that reform would take place within the framework of the 2008 Constitution of the Union of Myanmar, which preserves a central political role for the military. The Constitution provides that 25 per cent of members of state and federal parliaments must be serving army officers appointed by the commander-in-chief, and that the Constitution cannot be amended without the approval of more than 75 per cent of parliament. Under the Constitution, the commander-in-chief has a decisive say in the appointment of the president and two vice-presidents. Certain key cabinet positions (such as Home Affairs and Defence) are confined to active military personnel. The army is fiscally and administratively autonomous. Article 445 of the 2008 Constitution provides immunity for members of the former military government in relation to any act done in the execution of duty; article 20(b) of the Constitution states that the Defence Service has the right to independently administer and adjudicate all affairs of the armed forces; article 343 provides that in the adjudication of military justice, the decision of the Commander-in-Chief of the Defence Services is final and conclusive. In 2016, before the NLD assumed power after the November 2015 elections, Senior General Min Aung Hlaing reminded the people at the Armed Forces Day Parade that a political role for the military was essential to the stability and prosperity of the state (Reuters 2016b). 
Third, Suu Kyi has constantly reassured the military that she does not wish to see the prosecution of military officers for acts committed during the years of military rule. Suu Kyi publicly reiterated that she preferred processes that lead to healing rather than to opening wounds, that she had no desire for retribution and that she does not want to see anyone in the military stand trial for the human rights violations of the past. When she discussed mechanisms for accountability, which was rarely and reluctantly, it was in the form of a truth and reconciliation commission, similar to the South African commission. But in Suu Kyi's view, there was no urgency for the creation of such an institution (Naing 2012). Conscious of the need to placate the military during the period of transition, Suu Kyi embraced Myanmar's military, the Tatmadaw, as 'her father's army' and declared that she was 'very fond' of the army (BBC 2013).

Finally, the government intensified efforts to sign ceasefire agreements with ethnic minority armies. An official ceasefire with the Shan State Army-South (SSA-South) was signed at the end of 2011 (Oo 2011). On 12 January 2012, the government signed a ceasefire with the 19-member Karen National Union, to end hostilities between the military and the Karen National Liberation Army. The government also continued negotiations with the Chin National Front. In 2015, the government signed a Nationwide Ceasefire Agreement with eight armed ethnic organisations. Negotiations were complicated by decades of mistrust and by continuing uncertainty about whether the military was actually under the control of the government. In Kachin State, for example, a 14-yearlong ceasefire came to an end in 2011, when the Kachin Independence Army refused to accede to a request that it transform its military forces into a Border Guard force under the control of the Tatmadaw. President Thein Sein's orders that the army not launch attacks on ethnic armed groups in northern Kachin State were defied (Burma Partnership 2012).

For the Kachin, the NLD's victory in the elections of November 2015 changed little. Even as preparations got underway for another nationwide peace conference in August 2016, and at the same time that Aung San Suu Kyi was making a pledge to the nation that peace with ethnic groups was her first priority, the Tatmadaw was intensifying attacks on KIA positions. Hundreds of thousands of civilians were displaced. Government forces were accused of committing grave human rights violations. These include firing on unarmed civilians, including those sheltering in refugee camps; desecrating churches; the abduction and disappearance of villagers 
suspected of belonging to the KIA; razing homes, pillaging properties; using antipersonnel mines; conscripting forced labour; enlisting children to serve as army porters; torture; and rape (Human Rights Watch 2017).

From the perspective of the military, the NLD and leaders of armed ethnic organisations, the success of Myanmar's transition to democracy depended on the exclusion of the institutions and processes of transitional justice. The military's interest in defraying justice is comprehensible. Myanmar's transition was not the result of a change of guard among the top military leadership: prosecuting those ultimately responsible for war crimes and crimes against humanity would mean prosecuting the people who were driving transition. Aung San Suu Kyi and the NLD understood that focusing on retribution - or even calling for recognition of the crimes committed by the former military regime through the establishment of a truth commission - could destabilise the political situation and undermine prospects for further democratisation and peace. For leaders of ethnic armies, the primary demand was not for retribution or acknowledgement of the wrongs of the past - it was for a strong form of federalism that would preserve the autonomy and rights of ethnic states to manage their own governance and resources. The Nationwide Ceasefire Agreement did not include provisions for the establishment of criminal proceedings in relation to crimes committed by the military (or crimes committed by ethnic armies), nor did it refer to the establishment of truth commissions, nor did it refer to reparations. It did, however, refer to the pursuit of social and economic goals (protection of the environment, improvements to health and education, and addressing the chronic drug problem that exists in many ethnic states).

\section{The 'political stability before justice' argument in the context of Myanmar}

In 1991, Samuel Huntington set out the considerations that new democratic regimes must take into account in deciding how to address crimes committed by officials of the predecessor regime (Huntington 1991). In Huntington's view, the decision to prosecute and punish, or forgive and forget, did not turn on moral or legal arguments about societal obligations to truth, justice and the rule of law. Instead, the decision was determined by the nature of the democratisation process and the distribution of political power during and after transition. In Huntington's view, in circumstances where democratic transformations 
were initiated and guided by leaders of the existing authoritarian regime, assurances regarding non-prosecution - amnesties - were essential to prospects of democratic consolidation. Put simply, no authoritarian leader would enable transition if they anticipated being prosecuted as a result. Amnesty was the price of peaceful transformation. The question of whether prosecuting perpetrators of crimes in former regimes undermines prospects for democratic consolidation became one of the key debates in the scholarship on transitional justice (O'Donnell and Schmitter 1986; Huntington 1991; D’Amato 1994; Akhavan 2009; Snyder and Vinjamuri 2004; Kim and Sikkink 2010).

Recent scholarship has moved the debate about peaceful democratic transition versus pursuit of justice in different directions. First, via historical analysis of the different circumstances in which trials, amnesties or truth commissions contribute to stabilising new democracies, scholars have drawn attention to institutional combinations that appear to be effective in promoting democratic consolidation (for example, trials and truth commissions; amnesties and truth commissions) (Salehi and Williams 2016). Second, scholars have been attentive to temporal and sequencing issues in the establishment of transitional justice institutions and policies. Dancy and Wiebelhaus-Brahm, for example, in their study of transitions in Latin America, conclude that amnesties followed by trials, or trials followed by amnesties, are both sufficient conditions for democratic consolidation (Dancy and Wieblhaus-Brahm 2015). Third, the concept of transitional justice itself has been interrogated. Scholars have unpacked assumptions about the form that transitional justice should take and paid attention to local experiences, priorities and practices (Shaw and Waldorf 2010; Jeffrey and Kim 2014).

In Myanmar, the 'political stability versus justice' debate did not feature in public discourse during the early years of Myanmar's transition to democracy. This is because the military, which under the 2008 Constitution is not subject to civilian control, remained central to the transition, central to the governance of the state and central to the peace process with ethnic armies. It was clear to all primary political actors that retribution - and even truth-seeking, if implemented too early would undermine prospects for transition. This understanding shaped Myanmar's transition in two key ways.

First, for the military, a broad amnesty was a precondition for withdrawal from power. The constitutional immunity from prosecution for Myanmar's former military rulers, and their agents and personnel, and 
the Defence Service's right to independently administer and adjudicate all affairs of the armed force, was a non-negotiable condition of the bargain between the key actors in the transition. Immunity from prosecution for the military was one of the terms on which transition took place. Suu Kyi and her party understood that to challenge this would be to risk a resumption of power by the military and unravel the democratic advances that had been made (which included a relatively fair and free election in 2010 , and a parliament dominated by a democratic political party after the 2015 election).

Myanmar's political history was instructive for Suu Kyi and Myanmar's pro-democracy leaders. In general elections held in 1990, the NLD, led by Aung San Suu Kyi, won a sweeping victory, securing more than 50 per cent of the popular vote. The military, however, refused to transfer power to the NLD. The reason for this - in popular legend at least - was an offhand comment from U Kyi Maung, chairman of the NLD, who in a post-election press conference referred to 'Nuremberg-style tribunals' while explaining to a foreign journalist that the NLD did not intend to seek accountability for what the army had done to the people during its period of rule. 'Here in Myanmar', said Kyi Maung, 'we do not need any Nuremberg-style tribunals' (Jones 2014). Many people in Myanmar believe that one of the primary reasons why the Burmese military refused to relinquish power after the 1990 elections was because the generals feared they would be tried for crimes committed during the period of dictatorship (Kaung 2011; Jones 2014). The NLD was determined to ensure that history would not repeat itself and that in the 2012-2015 elections, the generals would not be frightened once again into retreating from reform. For Suu Kyi and the NLD, the high-level prosecution of members of the military was not a political possibility.

There are civil society organisations in Kachin State, and among the Kachin diaspora in Thailand, the United States and elsewhere, who still call for the establishment of the traditional mechanisms of transitional justice: in the first place, a UN-backed independent Commission of Inquiry on the human rights abuses being committed against the Kachin and other peoples, to put an end to impunity. But in the early years of transition even the United Nations seemed prepared to defer accountability and give democracy a chance to take root. In 2010, for example, the Special Rapporteur on the situation of human rights in Myanmar reported that the people of Myanmar had endured gross and systematic human rights violations that possibly amounted to crimes against humanity or war crimes 
under the terms of the Rome Statute of the International Criminal Court. The Rapporteur suggested the possible establishment of a Commission of Inquiry (United Nations General Assembly, Human Rights Council 2010, 2014). The United States and several other countries supported this suggestion. But after 2012, when Suu Kyi entered parliament, calls from within the UN for the establishment of a Commission of Inquiry abated. In 2013, the Special Rapporteur recommended merely the consideration of the establishment of a truth commission, to 'inform continuing democratic reform and national reconciliation' (United Nations General Assembly 2013).

Second, Myanmar's transition to democracy was complicated by the ongoing civil conflict with ethnic armed organisations. Civil war stood as a grave threat to democratic consolidation because while there was a prospect that conflict could lead to the secession of some ethnic states, the military would preserve its political independence and power to ensure the country remained unified. Myanmar's Deputy Minister for Foreign Affairs, His Excellency U Khin Maung Win wrote in 2004:

\begin{abstract}
Myanmar is a Union composed of more than one hundred different national races, each with its own culture and traditions. Politically, there cannot be lasting peace and stability in the country without national unity. Unfortunately, the divide and rule policy practiced by the British colonialists resulted in suspicion and discord among the national races. This subsequently led to armed insurgency that spread to various parts of the country for decades. The question of achieving national unity and bringing to an end the armed insurgency are vital issues for any government, past, present and future (Win 2004).
\end{abstract}

Again, the history is instructive. The 1962 military coup in Burma took place amid uprisings in ethnic states, because the military feared that unless they assumed control of the country the Union would disintegrate. Farrelly notes that 'anxiety about the potential for territorial fragmentation is the principle motivation for those who consider the military's role essential to national survival' (Farrelly 2014, 313). In 2010, the military's historical priority of preserving national unity was overlaid with the substantial economic interests of the military and their cronies, and of the Burmese and Chinese businesses who sought to preserve their investments (Renshaw 2017). 
The moral argument for deferring justice, made by the primary actors in the transition, was that the preservation and consolidation of democracy, within a united Myanmar, and all the goods that flow from democracy, requires peace and stability. Development, to improve the health, education and living standards of the people, also requires peace. Therefore, ran the argument, those who were genuinely interested in protecting human rights must support peace and political stability at all costs and if justice (by which they meant policies that sought accountability for past acts of the military) stood in the way of peace then justice should be deferred or sacrificed.

\section{Transition without justice: Leaving truth until tomorrow and leaving today to the rule of law}

What was offered to the people of Myanmar after the 2015 elections, instead of historical justice, were two things: (1) attention to the rule of law as a means for ensuring that abuses do not continue; and (2) a promise from Suu Kyi that, at some point in the future, there would come a time for seeking and telling the truth about Myanmar's past.

Over the past quarter of a century the precise nature and substance of 'the rule of law' has been the subject of vigorous debate (Krygier 2010). For Suu Kyi, throughout the long years of dictatorship, 'the rule of law' stood in opposition to the arbitrary exercise of state power by the military. The rule of law meant the enforcement of just laws, enacted with the authority of a democratically elected legislature, interpreted by an independent judiciary and enforced by an impartial police service. ${ }^{4}$ Under any commonly accepted understanding of the rule of law, these features are a centerpiece (Fuller 1964). In Myanmar, since 2012, the rule of law has been championed by both the military and Suu Kyi as a panacea for the ongoing abuses of power that accompanied military action in ethnic conflict zones. In 2016, for example, when the United Nations reported that military action in Rakhine State could amount to

4 See Nick Cheesman, Opposing the Rule of Law: How Myanmar's Courts Make Law and Order (Cambridge: Cambridge University Press, 2016) for an illuminating study of the conflation of the rule of law with law and order in Myanmar. Cheesman's argument is that law and order is neither consonant with the rule of law, nor a negative of the rule-of-law ideal; it is, in fact, what he calls 'asymmetrically opposed' to the rule of law. 
ethnic cleansing, Suu Kyi said: 'The Myanmar government is responding to the issue of Rakhine state based on the principles of the rule of law' (Funakoshi 2016).

For civil society organisations, an early test case of the potential for 'the rule of law' to bring justice was the government's response to public protests against the Letpadaung copper mine. In 2010, a company owned by the military, the Union of Myanmar Economic Holdings Ltd, confiscated 1,356 hectares of farmland in order to develop a copper mine in partnership with a Chinese industrial and arms manufacturer. On 29 November 2012, security forces violently dispersed a peaceful protest organised by Buddhist monks and local farmers whose land had been confiscated. Tear gas, smoke bombs and fire were used against the protesters as they slept in the early morning. The international media reported that the police used white phosphorous against protesters (Lwin 2013). The raid was justified by Myanmar's authorities on the grounds that permission had not been sought for the public protest. Suu Kyi visited the protest site immediately following the incident and told protesters that she would seek to negotiate a solution between mine operators and local communities.

In the wake of the incident, President Thein Sein formed a Parliamentary Commission to establish the facts and inquire whether mining should continue at Letpadaung. Aung San Suu Kyi was asked to chair the commission. In March 2013, the commission handed down its report. The report acknowledged that the mine had environmental consequences and that farmers were forcibly evicted from their land to make way for the project (Weng and Aye 2013a). But the report did not recommend the closure of the copper mine. Nor did it expose the perpetrators of the violence carried out on 29 November. Instead, the report advised the protesters to desist and the company to do three things: (1) provide jobs for people in local communities; (2) maintain a healthy environment; and (3) provide educational and healthcare benefits for local people. Aung San Suu Kyi told farmers that Myanmar could not afford to shut down the mine and risk turning away foreign investors, and that their protest was illegal: 'you all have to ask permission from the government if you protest as our country has the rule of law now. Those who do not respect the rule of law, they could get punished' (Weng and Aye 2013b).

Since her ascension to power, Suu Kyi has invoked the rule of law without necessarily being attentive to the legitimacy of laws themselves. The NLD, like the military, has used section 66(d) of the Telecommunications Law, 
introduced in 2015, to stifle criticism on social media (Free Expression Myanmar 2017). Section 66(d) provides for up to three years in prison for 'extorting, coercing, restraining wrongfully, defaming, disturbing, causing undue influence or threatening any person using a telecommunications network'. Provisions of the State Secrecy Act and the Unlawful Associations Act have also been used numerous times against citizens and members of community-based organisations. In July 2015, interfaith activists U Zaw Zaw Latt and Daw Pwint Phyu Latt were sentenced to four years imprisonment each - two under the Unlawful Associations Act and two under the 1947 Immigration Emergency Provisions Act for participating in an interfaith peace trip to territory controlled by the Kachin Independence Army (Lwin 2016).

In the case of the 2015 murder and rape of the two young Kachin schoolteachers, described at the beginning of this chapter, the military published a statement shortly after the incident, denying military involvement and stating that the Tatmadaw would take action based on the rule of law against anyone who alleged soldiers were involved in the crimes (Weng 2015). The President's Office supported the Tatmadaw's position, claiming that an accusation against an individual solider was an accusation against the Tatmadaw as an institution, and warning that the Tatmadaw had a right to defend itself by prosecuting those who make unfounded accusations (Weng 2015). The threat was not an idle one. In 2014, a team of journalists reported that chemical weapons were being produced in a secretive army installation in Pakokku Township. The three reporters, the journal's editor and its chief executive officer were charged under the State Secrets Act and sentenced to 10 years imprisonment with hard labour (Mann 2014). In another case, 25-year-old Chaw Sandi Tun posted a comment on Facebook likening the colour of Aung San Suu Kyi's dress to the colour of the military's uniform. She was charged with defamation under article 34(d) of the Electronic Transactions Law, which carries a penalty of up to five years in prison (Zin 2015). During the early years of Myanmar's transition, the 'rule of law' was invoked not to serve the people but to constrain their freedom.

The limited conception of the rule of law, as invoked by both the military and by Aung San Suu Kyi, suggests a political morality that may be out of kilter with the needs of a society that has been subjected to authoritarian rule and massive violations of human rights. In the aftermath of transitions from dictatorship and oppressive rule, the capacity of citizens (and their leaders) to distinguish between right and wrong, just and unjust, can 
be severely diminished (Minow 1998; Dyzenhaus 2000). One of the primary purposes of transitional justice is to assist societies to reconstruct the moral foundations necessary for a future stable democracy. Unless this is achieved, liberal values proclaimed by the new democratic regime risk sliding into what Dimitrijević describes as 'ritual facades without any legitimising and practical authority’ (Dimitrijević 2006, 374).

One example serves to illustrate the profoundly negative consequences of the decision made by Myanmar's leaders to adopt silence as a response to systemic human rights abuses that took place under military rule. In October 2016, the government announced that the military was commencing what it called a 'clearance operation' in northern Rakhine State, home to Myanmar's population of Rohingya Muslims, in response to an attack by armed insurgents on three border guard posts (Reuters 2016a). The area was sealed off, movement within the area was restricted and humanitarian agencies were denied access. The operation lasted from 9 October 2016 until 9 February 2017 (Republic of the Union of Myanmar, President's Office 2017). During that period, according to the High Commissioner for Human Rights, government forces carried out a series of atrocities against local Muslim populations (OHCHR 2017). These included the burning and looting of Rohingya villages; the murder of Rohingya men, women and children; summary execution of imams, religious scholars and community leaders; rape and torture. The military used helicopters to fire bullets and drop grenades on villagers as they were working on their farms, shopping in markets or fishing. Tens of thousands of villagers fled across the border to Bangladesh. 'Now is the worst it has ever been', said one Rohingya villager. 'We have heard from our grandparents that there were bad things happening in the past too, but never like this' (OHCHR 2017, 43).

What baffled observers of Myanmar's transition was the almost universal failure of Myanmar's leaders, including Aung San Suu Kyi, and large sections of Myanmar's public, to recognise the nature of the military's actions and the fact that the persecution of the Rohingya was of the same order as the persecution that they and their families had endured at the hands of the Tatmadaw during the decades of military rule. The response of much of the public to the Rohingya crisis, which was captured in print, social media and in large rallies held in support of the Tatmadaw's actions, speaks to an urgent need to transform the political culture of Myanmar. There is an argument that providing processes that permit people to acknowledge and understand the atrocities that mark a country's past, 
and uncover the systematic nature of violations and the motivational patterns that led to violations, helps both political leaders and citizens rebuild the moral foundations of their society (Minow 2002). Put simply, it must be publicly stated that there was no justification for the murder, rape, torture and disappearance of tens of thousands of people during the decades of military rule. Truth commissions, in other parts of the world, have contributed to this task; though the evidence of their impact is still debated (Crocker 1999; Brahm 2007). In Myanmar's case, the atrocities perpetrated over so many years across the entire country might tend to suggest a need for multiple commissions, or multiple strands to a commission's mandate. For example, there have been demands for the investigation of crimes committed in ethnic states in order to terrorise local populations and suppress insurgencies; acknowledgement of crimes of torture, extrajudicial killing, disappearance and false imprisonment to contain political opponents of the regime; and acknowledgement, apologies and reparation for gender-based crimes against women. Myanmar's leaders, however, argued that there were other national priorities that outweighed the need to recognise and repair past violence. There are no immediate prospects for the establishment of an official truth commission in Myanmar.

\section{The contribution of civil society organisations to transitional justice in Myanmar}

In the immediate aftermath of the murders of $\mathrm{Ra}$ and Tsin, the KBC organised a procession to accompany the two-day journey of the coffins from Shan State to the Kachin State capital Myitkyina. As the coffins processed through the countryside, large crowds stood by the side of the road to watch and pray. When the coffins reached Myitkyina, enormous crowds gathered for multifaith prayer services in honour of the two teachers. Since then, each year, on the anniversary of their deaths, the KBC has held prayer services across the Kachin region and in Kachin communities around the world, to remember the women and affirm the need for justice in relation to their deaths (Nyein 2018). The significance of these actions can only be understood if one appreciates the scale of abuse that took place in Myanmar during military rule: the routine brutality of the military in its treatment of villagers; the uncounted numbers of men, women and children who were killed and whose bodies were buried without markers; the fear of arbitrary torture, 
rape and imprisonment with which ordinary people lived their everyday lives (KWAT 2011). The military presence within the village where the two girls were staying and the grossly inadequate police investigation mirrored thousands of other cases that had taken place during the years of military rule. Ra and Tsin came to stand for all of them. By memorialising the deaths of two individuals such as $\mathrm{Ra}$ and Tsin, the $\mathrm{KBC}$ was making a statement that the truth of wrongs must be told and that each individual life is of value. The deep grief and outrage that marked the community's response to the death of the two schoolteachers was a deeply authentic and powerful response. People from across Kachin State, Shan State and throughout Myanmar, recognising the innocence of the victims, their youth, their vocation as teachers and the brutality of their murders, identified with the tragedy and, under the leadership of the KBC, shaped their response as a political one.

In Kachin, from the mid-1990s, the leadership of religious and community-based organisations became more pronounced in the wake of disillusionment with the political leadership of armed ethnic organisations. A peace deal signed between the military and the Kachin Independence Organisation (KIO) in 1994 brought with it the potential for local Kachin political leaders to make large amounts of money. Local Kachin strongmen exploited the natural resources of the state in collaboration with the Tatmadaw and Chinese companies. The business methods of the KIO were often indistinguishable from those of the Tatmadaw, and included cronyism, land-grabbing, exploitation and tactics of terror against local populations. There was little consultation between KIO leaders and the people about economic decisions that affected their lives (Woods 2011). Community leadership during this period came from the local churches, schools and community-based organisations. During the period of the ceasefire, the $\mathrm{KBC}$ was a major provider of healthcare and education services to the Kachin people. The KBC, with other religious leadership groups such as the Kachin Catholic Bishops Conference, has through the KBC Committee for Peace and Reconciliation led demands for the political rights of the Kachin. The demands are principally for political autonomy for Kachin through a federal political structure. The KBC has also pressed for accountability in relation to specific human rights violations such as the murders of $\mathrm{Ra}$ and $\mathrm{Tsin}$. In the wake of the murders, the $\mathrm{KBC}$ announced that it had created a 15 -member committee, composed of leaders of the $\mathrm{KBC}$, other religious leaders, civil society representatives and lawyers, to independently investigate the 
crime. The military cooperated, to an extent, with the $\mathrm{KBC}$ investigators, although it did not permit the KBC Committee to ask questions directly to Burmese military officers (Gam 2017). The KBC investigation into the deaths of $\mathrm{Ra}$ and Tsin is ongoing.

The $\mathrm{KBC}$ is not the only CSO focused on the issue of transitional justice. The work of ND-Burma is particularly notable. ND-Burma was founded in 2004 with the objective of training local organisations in the collection and management of human rights documentation. ND-Burma coordinates members' input into a common database and engages in advocacy campaigns, seeking accountability in individual cases and broader justice (government recognition, redress and guarantees of non-recurrence for victims of human rights violations). Its vision is explicitly political - 'a peaceful, democratic and federal Burma that has acknowledged past human rights violations and has implemented measures to uphold the dignity of victims and guard against recurrence' (ND-Burma 2018). It membership includes both local organisations (Assistance Association for Political Prisoners - Burma; Kachin Development Networking Group; Human Rights Foundation of Monland; Kachin Women's Association Thailand; Palaung Women's Organization; Ta'ang Students and Youth Organization; Tavoyan Women's Union) and affiliate members based outside Myanmar with strong international connections (such as EarthRights International and the International Center for Transitional Justice).

In relation to the murder of $\mathrm{Ra}$ and Tsin, ND-Burma (through its member organisation the Kachin Women's Association Thailand), like the KBC, made inquiries and investigations into the incident and aimed to produce its own report of what had taken place. There are significant differences, however, in the approach and purpose of the work of $\mathrm{CBO}$ s such as the $\mathrm{KBC}$ and ND-Burma, even when both are focused on the same issue.

ND-Burma self-consciously refers to itself as an 'Unofficial Truth Project' (ND-Burma 2015). Several of ND-Burma's various reports, including the milestone 'To Recognize and Repair: Unofficial Truth Projects and the Need for Justice in Burma' (ND-Burma 2015) were funded by Open Society Foundations. To provide a framework for collaboration among members, ND-Burma has developed a 'controlled vocabulary' of the categories of human rights violations on which the network focuses. Its aim is to collate the data that will one day be used by an official truth commission. The group recognises that while many parts of the country are 
still in conflict and the military still retains a significant degree of power, a state-led initiative is unlikely to be established and, even if it were, there would be serious and justifiable questions about its neutrality. In these circumstances, ND-Burma's approach is to engage local communities as active participants in the first stage of what they hope will eventually be a government-supported process (Holliday 2014).

ND-Burma operates with funding from international NGOs, with input from international donors, using a controlled vocabulary of wrongs, with a long-term vision of presenting evidence before an officially sanctioned Commission. Bickford (2007) notes that there is something potentially troubling about the similarities among Unofficial Truth Projects across the world, as it suggests 'an overly scientific approach to truth-telling, as if there is one way to do it, and all these efforts are converging on the formula'. Yet the point of grassroots measures is that there should be no formula - efforts should be context-driven and capture the specificity of local circumstances. With efforts to formalise data collection and recordkeeping comes not just the problem of categorisation and formula which arguably distances the victim from the truth of their story - but also an implicit promise that the story, so told, will eventually be officially recognised and form part of an official narrative. There is the potential for disillusionment if this promise to victims is not fulfilled.

The Kachin Baptist Convention and ND-Burma, together with other civil society organisations, advocate for redress of both current and historical wrongs committed by both the Tatmadaw and by ethnic armies. Unless there is an end to impunity, they argue, crimes such as those committed against $\mathrm{Ra}$ and Tsin will continue to be committed. From one perspective, this demand has been registered and responded to by both the military and the government of Aung San Suu Kyi. Both acknowledge the need for military accountability and both champion the rule of law as a tool for addressing human rights violations. The Kachin Baptist Convention requested, and was officially given, an active role in the investigation into the murder of $\mathrm{Ra}$ and Tsin. Yet in relation to calls for justice for historical wrongs, there is little appetite on the part of the military or Suu Kyi to institute any of the formal mechanisms of transitional justice. Nonetheless, by memorialising the death of victims such as Ra and Tsin, the $\mathrm{KBC}$ makes a profoundly significant contribution to transitional justice in Myanmar. 
Both ND-Burma and the KBC form a discordant note in Suu Kyi's narrative that the military, ethnic leaders and the National League for Democracy must walk forward 'hand in hand' towards a new future, without looking back at the past. Both ND-Burma and the KBC draw a clear line between the failure to prosecute members of the military for crimes carried out in the past, and the continuing commission of crimes. There appears to be, from the outpouring of grief that marked the death of Tsin and $\mathrm{Ra}$, and in the testimonies collected by ND-Burma, an urge to confront the past that is not in accord with Suu Kyi's emphasis on 'moving on' and 'healing not retribution'.

\section{Conclusion}

To date, there has been little justice, in any form, in Myanmar's transition to democracy. The explanation for this is threefold. First, Myanmar's transition to democracy is the result of indigenous top-down change, and not the result of revolution, or an unopposable groundswell of popular opposition or the efforts of the political opposition. The military remains a major player in the transition to democracy, and retains a significant degree of political power. The interests of the National League for Democracy are primarily to affect a peaceful and stable transition, and this goal is not seen as consistent with the establishment of strong accountability mechanisms. For this reason, unofficial truth projects and memorialisations are taking place in parts of Myanmar, but national-level justice projects are not on the agenda of any of the main political actors.

Second, justice as conceived by many people in Myanmar is broadly imagined, encompassing political reform (a federal structure with highly autonomous ethnic states) and economic reform (land redistribution and control of natural resources by the states). This is precisely the kind of justice that the country's new leaders, the National League for Democracy, will struggle to deliver in a context where the military must be appeased and the economic interests of powerful investors in Myanmar and China protected.

Third, armed conflict resumed in Kachin State at precisely the same time as the transition to democracy got underway. Questions of timing are crucial in matters of transitional justice. There are perceptions in states such as Kachin State and outside it that pressing too hard for historical justice might undermine prospects for peace. 
The difficulty is that Myanmar's modern history is marked by political betrayal and the broken promises of the military: the failure to create a genuinely federal state in 1947 after independence; the failure to hand power to the NLD after the elections of 1990; and myriad other betrayals from land-grabbing to unfair trials. Many ethnic groups, such as the Kachin in the far north of Myanmar, have attempted in the past to follow the path of democracy and peace before justice. The dividends have been difficult to discern. Why, ask many, should they now trust the promise, made by both the Tatmadaw and Aung San Suu Kyi, that justice will follow peace and democracy? They argue that unless there is justice, peace will be impossible. There is a sense that transition is yet another elite pact, and that their suffering has no recognition. Furthermore, as military action in conflict zones increases, as evidence of current human rights abuses by the military grow, and as the foreign media and independent observers are prevented from witnessing what is occurring in conflict zones, the price of the pact between Suu Kyi and the Tatmadaw seems by some to be too high.

In relation to human rights abuses committed by the military during the decades of dictatorship, neither the military nor Aung San Suu Kyi have indicated that they will countenance retribution. Truth is a possibility, but it is a long way off. The focus of the military and Suu Kyi is on pursuing a path towards an imperfect but achievable form of constitutional democracy. They demand that victims of human rights violations forgo their right to revisit the past and seek a truthful accounting of, and justice for, the crimes of the past. What Suu Kyi and the military offer instead is piecemeal justice administered by the new government according to a narrow interpretation of the rule of law; and hopefully peace, so that a larger justice might be negotiated at some later point. What is clear is that, in this context, civil society organisations are critical actors in recording and articulating alternative expressions of what justice requires; and beginning the long process of recalibrating the political morality of post-transition society.

\section{Bibliography}

Akhavan, Payam. 2009. 'Are International Criminal Tribunals a Disincentive to Peace?: Reconciling Judicial Romanticism with Political Realism'. Human Rights Quarterly 31 (3): 624-654. doi.org/10.1353/hrq.0.0096. 
BBC (British Broadcasting Corporation). 2013. 'Aung San Suu Kyi Tells of Fondness for Burma Army'. BBC News. Video, 27 January. www.bbc.com/ news/av/world-asia-pacific-21224307/aung-san-suu-kyi-tells-of-fondnessfor-burma-army.

Bickford, Louis. 2007. 'Unofficial Truth Projects'. Human Rights Quarterly 29: 994-1035. doi.org/10.1353/hrq.2007.0036.

Brahm, Eric. 2007. 'Uncovering the Truth: Examining Truth Commission Success and Impact'. International Studies Perspectives 8: 16-35. doi.org/10.1111/ j.1528-3585.2007.00267.x.

Burma Partnership. 2012. '2012: A Year for Cautious Optimism'. Burma Partnership (blog), 9 January. www.burmapartnership.org/2012/01/2012-ayear-for-cautious-optimism/.

Crocker, David. 1999. 'Reckoning with Past Wrongs: A Normative Framework'. Ethics and InternationalAffairs 13:43-63. doi.org/10.1111/j.1747-7093.1999. tb00326.x.

D’Amato, Anthony. 1994. 'Peace vs. Accountability in Bosnia'. American Journal of International Law 88 (3): 500-506. doi.org/10.2307/2203717.

Dancy, Geoff and Eric Wiebelhaus-Brahm. 2015. 'Timing, Sequencing, and Transitional Justice Impact: A Qualitative Comparative Analysis of Latin America'. Human Rights Review 16 (4): 321-342. doi.org/10.1007/s12142015-0374-2.

Dimitrijević, Nenad. 2006. 'Justice beyond Blame: Moral Justification of (the Idea of) a Truth Commission'. The Journal of Conflict Resolution 50 (3): 368-382. doi.org/10.1177/0022002706286952.

Dyzenhaus, David. 2000. 'Justifying the Truth and Reconciliation Commission'. Journal of Political Philosophy 8: 473-492.

Farrelly, Nicholas. 2014. 'Law, War, Politics: Reflections on Violence and the Kachin'. In Law, Society and Transition in Myanmar, edited by Melissa Crouch, and Tim Lindsey, 305-322. Oxford: Hart Publishing.

Free Expression Myanmar. 2017. Website. freeexpressionmyanmar.org/ (accessed 2017).

Fuller, Lon. 1964. The Morality of Law. New Haven and London: Yale University Press. 
Funakoshi, Minami. 2016. 'Suu Kyi Says "Delicate” Myanmar Conflict Handled by Rule of Law'. Reuters, 3 November. www.reuters.com/article/us-myanmarjapan-idUSKBN12Y0B0.

Gam, Nmang. 2017. 'Two Years On, No Justice for Two Murdered Kachin Teachers'. Kachinland News, 20 January. www.kachinlandnews.com/?p=27451.

Hann, Chris. 2011. Zivilgesellschaft, In Lexikon der Globalisierung, edited by Fernand Kreff, Eva-Maria Knoll and Andre Gingrich, Bielefeld: Transcript Verlag.

Heidel, Brian. 2006. The Growth of Civil Society in Myanmar. Bangalore: Books for Change.

Holliday, Ian. 2014. 'Thinking about Transitional Justice in Myanmar'. South East Asia Research 22: 183-200. doi.org/10.5367/sear.2014.0204.

Holmes, Oliver. 2016. 'Aung San Suu Kyi Set to Get PM-Type Role in Myanmar Government'. The Guardian, 1 April.

Human Rights Watch. 2017. 'World Report: Burma: Events of 2016', www.hrw. org/world-report/2017/country-chapters/burma.

Huntington, Samuel P. 1991. The Third Wave: Democratization in the Late Twentieth Century. Norman: University of Oklahoma Press.

Jacquet, Carine. 2015. The Kachin Conflict: Testing the Limits of the Political Transition in Myanmar. Bangkok: Institut de Recherche sur l'Asie du Sud-Est Contemporaine (Research Institute on Contemporary Southeast Asia). doi.org/10.4000/books.irasec. 241 .

Jeffery, Renée and Hun Joon Kim. 2014. Transitional Justice in the Asia-Pacific. New York: Cambridge University Press.

Jones, Lee. 2014. 'The Political Economy of Myanmar's Transition'. Journal of Contemporary Asia 44 (1): 144-170. doi.org/10.1080/00472336.2013.7 64143 .

Kaung, B. A. 2011. 'EC Chief Says NLD Threatened Junta with "Nuremburgstyle" Trial'. The Irrawaddy, 29 July. www2.irrawaddy.com/article.php?art_ $\mathrm{id}=21796$.

Kim, Hunjoon and Kathryn Sikkink. 2010. 'Explaining the Deterrence Effect of Human Rights Prosecutions for Transitional Countries'. International Studies Quarterly 54 (4): 939-963. doi.org/10.1111/j.1468-2478.2010.00621.x. 
Kramer, Tom. 2011. Civil Society Gaining Ground. Opportunities for Change and Development in Burma. Amsterdam: Transnational Institute (TNI)/Burma Centrum Netherlands (BCN).

Krygier, Martin. 2010. 'Four Puzzles About the Rule of Law: Why, What, Where? And who cares?'. Nomos - American Society for Political and Legal Philosophy 50 (64): 64-104. doi.org/10.18574/nyu/9780814728437.003.0004.

KWAT (Kachin Women's Association Thailand). 2011. Burma's Covered Up War: Atrocities against the Kachin People. Chiang Mai, Thailand: KWAT.

Lidauer, Michael. 2012. 'Democratic Dawn? Civil Society and Elections in Myanmar 2010-2012'. Journal of Current Southeast Asian Affairs 31 (2): 87-114. doi.org/10.1177/186810341203100204.

Lwin, Ei Ei Toe. 2013. 'Commission Stalls, Tension Rises'. Myanmar Times, 4 February. www.mmtimes.com/national-news/3965-commission-stallstension-rises.html.

Lwin, Si Thu. 2016. 'Interfaith Activists Convicted, Given Two Years in Prison'. Myanmar Times, 29 February. www.mmtimes.com/national-news/mandalayupper-myanmar/19211-interfaith-activists-convicted-given-two-years-inprison.html.

Mann, Zarni. 2014. 'Journalists Detained for Reporting Alleged Burmese Chemical Weapons Factory'. The Irawaddy, 2 February. www.irrawaddy. $\mathrm{com} /$ news/burma/journalists-detained-reporting-alleged-burmese-chemicalweapons-factory.html.

Minow, Martha. 1998. Between Vengeance and Forgiveness: Facing History after Genocide and Mass Violence. Boston: Beacon.

Minow, Martha. 2002. Breaking the Cycles of Hatred: Memory, Law, and Repair. Princeton: Princeton University Press.

Myers, Steven Lee. 2011. 'In Myanmar, Government Reforms Win Over Some Sceptics'. The New York Times, 30 November. www.nytimes.com/2011/11/ 30/world/asia/in-myanmar-government-reforms-win-over-countrys-skeptics. html.

Naing, Saw Yan. 2012. 'Burma "Not Ready" for Truth Commission'. The Irrawaddy, 15 June. www.irrawaddy.org/human-rights/burma-not-readyfor-truth-commission.html.

ND-Burma. 2015. 'To Recognize and Repair'. nd-burma.org/to-recognize-andrepair/ (accessed 2018). 
ND-Burma. 2018. 'About Us'. nd-burma.org/about-us/ (accessed 2018).

Nyein, Nyein. 2018. 'Three Years On, Still No Progress in Rape and Murder of 2 Kachin Teachers'. The Irrawaddy, 19 January. www.irrawaddy.com/news/ burma/three-years-still-no-progress-rape-murder-2-kachin-teachers.html.

O’Donnell, Guillermo and Philippe C. Schmitter, eds. 1986. Transitions from Authoritarian Rule. Baltimore: Johns Hopkins University Press.

OHCHR (Office of the United Nations High Commissioner for Human Rights). 2017. Report of OHCHR Mission to Bangladesh: Interviews with Rohingyas Fleeing from Myanmar since 9 October 2016, 3 February.

Oo, Aung Naing. 2011. 'Give Peace in Burma a Chance'. The Irrawaddy, 13 December. www2.irrawaddy.com/article.php?art_id=22642\&page=2.

Prasse-Freeman, Elliott. 2012. 'Power, Civil Society, and an Inchoate Politics of the Daily in Burma/Myanmar'. The Journal of Asian Studies 71 (2): 371-397. doi.org/10.1017/S0021911812000083.

Renshaw, Catherine. 2013. 'Democratic Transformation and Regional Institutions: The Case of Myanmar and ASEAN'. Journal of Current Southeast Asian Affairs 32 (1): 29-54. doi.org/10.1177/186810341303200102.

Renshaw, Catherine. 2014. 'Disasters, Despots and Gun-Boat Diplomacy'. In The International Law of Disaster Relief, edited by David D. Caron, Michael J. Kelly and Anastasia Telesetky, 164-189. Cambridge: Cambridge University Press. doi.org/10.1017/CBO9781107447844.015.

Renshaw, Catherine. 2016. 'Human Rights under the New Regime'. In Constitutionalism and Legal Change in Myanmar, edited by Andrew Harding, 215-234. Oxford: Hart Publishing/Bloomsbury.

Renshaw, Catherine. 2017. 'Myanmar and Sanctions'. In The Business of Transition, edited by Melissa Crouch, 228-254. Cambridge: Cambridge University Press.

Republic of the Union of Myanmar, President's Office. 2017. 'Tatmataw Ends Area Clearance Operations in Northern Rakhine'. www.president-office.gov. $\mathrm{mm} / \mathrm{en} /$ ?q=issues/rakhine-state-affairs/id-7288.

Reuters. 2016a. 'Clashes in Myanmar's Rakhine Raise Weekend Death Toll to about 30: State Media'. 14 November. www.reuters.com/article/us-myanmarrohingya/clashes-in-myanmars-rakhine-raise-weekend-death-toll-to-about30-state-media-idUSKBN1390H3. 
Reuters. 2016b. 'Myanmar Army Reasserts its Key Political Role Ahead of Transition'. 27 March. www.reuters.com/article/us-myanmar-military/ myanmar-army-reasserts-its-key-political-role-ahead-of-transition-idUSKC N0WT05N.

Sadan, Mandy. 2015. 'Myanmar: Ongoing Conflict in Kachin State'. In Southeast Asian Affairs 2015, edited by Daljit Singh, 246-259. Singapore: Institute of Southeast Asian Studies. doi.org/10.1355/9789814620598-017.

Salehi, Mariam and Timothy Williams. 2016. 'Beyond Peace vs. Justice: Assessing Transitional Justice's Impact on Enduring Peace'. Transitional Justice Review 1 (4): 96-123. doi.org/10.5206/tjr.2016.1.4.4.

Shaw, Rosalind and Lars Waldorf. 2010. 'Introduction: Localizing Transitional Justice'. In Localizing Transitional Justice: Interventions and Priorities After Mass Violence, edited by Rosalind Shaw and Lars Waldorf, 3-27. Redwood City, CA: Stanford University Press.

Snyder, Jack and Leslie Vinjamuri. 2004. 'Trials and Errors: Principle and Pragmatism in Strategies of International Justice'. International Security 28 (3): 5-44. doi.org/10.1162/016228803773100066.

South, Ashley. 2008. Civil Society in Burma: The Development of Democracy amidst Conflict. Washington DC: East-West Center. doi.org/10.1355/97898 12309051.

Turnell, Sean. 2008. 'Burma's Economy 2008: Current Situation and Prospects for Reform'. Working Paper, Burma Economic Watch, Sydney, Australia.

United Nations General Assembly. 2013. Report of the Special Rapporteur of the Commission of Human Rights on the Situation of Human Rights in Myanmar. UN Doc. A/68/397 (23 September 2013).

United Nations General Assembly, Human Rights Council. 2010. Progress Report of the Special Rapporteur on the Situation of Human Rights in Myanmar, Tomás Ojea Quintan. UN Doc. A/HRC/13/48 (10 March 2010).

United Nations General Assembly, Human Rights Council. 2014. Report of the Special Rapporteur on the Situation of Human Rights in Myanmar, Tomás Ojea Quintana. UN Doc. A/HRC/25/64 (2 April 2014).

Weng, Lawi. 2015. 'Army Statement Warns against Linking Teachers' Murders to Troops'. The Irawaddy, 29 January. www.irrawaddy.com/news/burma/armystatement-warns-linking-teachers-murders-troops.html. 
Weng, Lawi and Thet Swe Aye. 2013a. 'Activists, Locals Reject Letpadaung Inquiry'. The Irrawaddy, 12 March. www.irrawaddy.com/news/burma/ activists-locals-reject-letpadaung-inquiry.html.

Weng, Lawi and Thet Swe Aye. 2013b. 'Stop Protests against Copper Mine, Suu Kyi Tells communities'. The Irrawaddy, 13 May. www.irrawaddy.com/news/burma/ stop-protests-against-copper-mine-suu-kyi-tells-communities.html.

Win, H.E. U Khin Maung. 2004. 'Myanmar Roadmap to Democracy: The Way Forward' (2004) Paper presented at the Seminar on Understanding Myanmar Yangon, 27-28 January, Myanmar Institute of Strategic and International Studies.

Woods, Kevin. 2011. 'Ceasefire Capitalism: Military-Private Partnerships, Resource Concessions and Military-State Building in the Burma-China Borderlands'. Journal of Peasant Studies 38 (4): 747-770. doi.org/10.1080/ 03066150.2011.607699.

Zin, Salai Thant. 2015. 'Woman Faces 5 Years over Photo Likening Army Garb to Suu Kyi's Dress'. The Irrawaddy, 13 October. www.irrawaddy.com/news/ burma/woman-faces-5-years-over-photo-likening-army-garb-to-suu-kyisdress.html. 
This text is taken from Civil Society and Transitional Justice in Asia and the Pacific, edited by Lia Kent, Joanne Wallis and Claire Cronin, published 2019 by ANU Press, The Australian National University,

Canberra, Australia.

doi.org/10.22459/CSTJAP.2019.06 